\title{
Usage and Quality of Formal Child Care Services Experienced by Infants and Toddlers in Foster and Kinship Care: An Australian Study
}

\author{
Sarah Wise ${ }^{1,2}$ (D)
}

Published online: 13 February 2018

(C) The Author(s) 2018. This article is an open access publication

\begin{abstract}
This research uses data from the Early Childhood in Foster and Kinship Care (ECIFKC) study to identify the proportion of young children, under 2 years of age, in foster and kinship care who use formal child care; weekly hours of child care; predictors of weekly hours of child care; and quality of care experienced. The sample for these analyses involved 39 foster and kinship care children. A higher proportion of ECIFKC children used child care compared to same-aged Australian peers and experienced more weekly hours of child care than other Australian children. Quality of child care was broadly the same as for other young Australian children. Factors associated with more weekly hours of child care included living in a placement with a single caregiver and being in a placement with a sibling. This finding suggested that child care participation may be provided with the goal of respite for caregivers. While the child care experienced met Australian national quality standards, the long hours that some children spent in child care is concerning. It is also unclear whether extra supports and quality features may be important to meet the special needs of foster and kinship care children in child care settings.
\end{abstract}

Keywords Child care · Foster care - Kinship care - Out-of-home care · Trauma • Child development

Résumé Cette recherche utilise des données de l'étude de l'ECIFKC (Early Childhood in Foster and Kinship Care) (petite enfance en familles d'accueil et aux soins de la parenté) afin d'identifier la proportion de jeunes enfants de moins de deux ans, en familles d'accueil et aux soins de la parenté qui fréquentent un service

Sarah Wise

sarah.wise@unimelb.edu.au

1 The Berry Street Childhood Institute, 1 Salisbury Street, Richmond, VIC 3121, Australia

2 The University of Melbourne, 161 Barry Street, Carlton, VIC 3053, Australia 
de garde à l'enfance formel, le nombre d'heures hebdomadaires de garde, les facteurs prédictifs de ce nombre d'heures hebdomadaires de garde et la qualité des soins reçus en service de garde. Pour ces analyses, l'échantillon est constitué de 39 enfants en familles d'accueil et aux soins de la parenté. Une plus forte proportion d'enfants de l'ECIFKC fréquente les services de garde que leurs pairs australiens, et pour un plus grand nombre d'heures par semaine que les autres enfants australiens. La qualité des services de garde est globalement la même que pour les autres jeunes enfants australiens. Les facteurs associés à un nombre plus élevé d'heures hebdomadaires de garde sont le placement confié à une seule personne responsable et le placement avec un frère ou une sœur. Ce résultat suggère que la fréquentation d'un service de garde peut avoir pour but de donner du répit à la personne responsable. Si le service de garde reçu correspond aux normes de qualité nationales australiennes, les longues heures que certains enfants passent en service de garde sont préoccupantes. Il n'est pas clair non plus si un soutien et des caractéristiques de qualité additionnels peuvent être importants pour répondre aux besoins spéciaux des enfants en familles d'accueil et aux soins de la parenté en milieux de garde.

Resumen Este trabajo de investigación utiliza datos del estudio de la Primera Infancia en Situación de Acogimiento Familiar en Familia Ajena o en Familia Extensa (ECIFKC, por su sigla en inglés) para identificar los niños menores de dos años viviendo con una familia de acogida y que asisten a una guardería formalmente establecida, el número de horas semanales de asistencia, los indicadores de horas de asistencia semanales, y la calidad de la atención infantil recibida. La muestra para estos análisis incluyó a 39 niños en acogimiento familiar en familia ajena y extensa. Más niños del grupo ECIFKC iban a guarderías, y asistían más horas por semana, en comparación con otros niños australianos de la misma edad. En términos generales, la calidad del servicio en las guarderías era el mismo que el que reciben otros niños pequeños australianos. Entre los factores asociados a una asistencia de más horas semanales se incluía el hecho de que los niños vivían en una acogida con un único cuidador y vivían en acogida con un hermano o hermana. Ello sugiere que la asistencia a la guardería cumpliría el objetivo de brindarles un alivio a los cuidadores. Si bien la atención brindada en las guarderías cumplía con las normas nacionales de calidad exigidas en Australia, es preocupante que algunos niños pasen tantas horas en la guardería. Además, queda poco claro si ofrecer mayor apoyo y un mejor nivel de calidad serían puntos importantes para cubrir las necesidades especiales de niños en situación de acogimiento en familia ajena o extensa.

\section{Introduction}

Globally, many young children are placed in full-time, out-of-home care because adverse family circumstances determine that the child's safety and well-being are best served by an alternative placement. In Australia, government departments initially attempt to find appropriate kinship care options (care provided by a family member or a member of the child's community) before identifying foster care placements (care in a family which has no previous connections to the child's 
family). Very young children in kinship and foster care are likely to have experienced a range of adverse circumstances, including prenatal exposure to alcohol and drugs, abuse and neglect, which may lead to a broad range of symptoms and difficulties (Pechtel and Pizzagalli 2010; Anda et al. 2006). Child care is one feature of young children's experience that can play a significant role in development, including for children in kinship or foster care. The aim of this research is to report on the usage of formal child care services experienced by foster and kinship care children under 2 years of age, predictors of weekly hours of child care, and quality of care experienced.

\section{Developmental Vulnerability of Very Young Children in Foster and Kinship Care}

In Australia, for the year 2015-2016, the out-of-home placement rate of children aged under 5 years was 3.8 per 1000 children. Indigenous Australian children are around 10 times more likely to be in out-of-home care compared to non-Indigenous Australian children. The continuous length of time in out-of-home care varies, although most children placed in out-of-home care in Australia spend more than 1 year in such care (Australian Institute of Health and Welfare 2017).

Very young children in foster and kinship care may experience a broad range of symptoms and difficulties if their mother is anxious, stressed or depressed and/or if she has used alcohol and drugs during pregnancy (Bruce et al. 2009). There is also strong scientific evidence to show that frequent and/or unremitting trauma in early childhood creates "toxic stress" that is associated with neural network abnormalities in areas of the brain responsible for memory, attention, impulsiveness, and behavioural control (Committee on Psychosocial Aspects of Child and Family Health et al. 2011). Due to a background of maltreatment and unstable caregiving, young children in foster and kinship care may also be at significant risk of developing attachment disorders (Lang et al. 2016). Young children may also have missed out on learning opportunities and appropriate physical care in their biological homes during a time of extraordinarily rapid learning.

In Australia, the New South Wales Pathways of Care Longitudinal Study (Australian Institute of Family Studies et al. 2015) showed high rates of atypical development among out-of-home care children at initial data collection. Concerns for speech development were reported for 27\% of children, aged 9-23 months, and high levels of behaviour problems were reported for $17 \%$ of children, aged 12-35 months. These concerns were also evident in the second National Survey of Child and Adolescent Well-Being conducted in the US. Casanueva et al. (2011) reported that $13 \%$ of children in kinship care and $19 \%$ of children in foster care, aged less than 6 years, had concerning speech development, while $20 \%$ of children in kinship care and $30 \%$ of children in foster care at 12-18 months had high levels of behaviour problems. For children, aged 3-24 months, 39\% of children in kinship care and $68 \%$ of children in foster care were at risk for neurodevelopmental delay.

The rate of out-of-home care admission among very young children and their special needs raises questions about how to best support their development in outof-home care contexts that can also carry risks for development and trauma. Child 
care is a common feature of young children's experience that can play a significant role in supporting development. The following sections discuss the implications of early child care for children, generally, and foster and kinship care specifically, as well as what is currently known about the use of formal (regulated) child care among Australian children in foster and kinship care in the first 2 years.

\section{Child Care Effects in the First Two Years}

There is a substantial body of research which explains the effects of child care experiences on children in the general population. High-quality centre care and preschool programs from 3 years of age have a positive impact on children's cognitive skills and behavioural outcomes, especially for children from low-income backgrounds (Love et al. 2005). However, evidence on the effects of ordinarily available child care in the first 2-3 years has been mixed (Australian Institute of Health and Welfare 2015; Jaffe et al. 2011; Melhuish et al. 2015).

While quality of care may balance the risk of time in care, a strong association has been found for longer hours of non-parental child care (more than $10 \mathrm{~h}$ weekly) and risks for antisocial behaviour at later ages in the US (Belsky et al. 2007; NICHD Early Childcare Research Network 2005), the UK (Melhuish 2010), Canada (Baker et al. 2008), and in Australia (Yamauchi and Leigh 2011). Greater negative behavioural effects are evident for children with the younger starting ages (Loeb et al. 2007).

Some studies have found that child care may be detrimental to cognitivelanguage development if a child enters child care in the first year of life (Melhuish 2004; Sylva et al. 2004, 2010; NICHD Early Childcare Research Network 2004), although findings from the UK Families, Children and Child Care Study differ (Barnes and Melhuish 2017). Studies have also shown that for children where the quality of care at child care is better than what is experienced in the home, then early child care (at ages less than 2 years) may be advantageous to cognitive outcomes (Hanson and Hawkes 2009; Kalb et al. 2014; Berry et al. 2016).

\section{Child Care Effects for Infants and Toddlers in Foster and Kinship Care}

The effects of child care on foster and kinship care children are complex, especially in the first 2 years. Over and above the potentially negative effects of early and extensive child care discussed above, the special needs of foster and kinship care children put them at risk for stressful encounters in child care (Mathers et al. 2016). Child care could also potentially interfere with the formation of an attachment bond with a new foster or kinship caregiver.

Conversely, high-quality child care may protect children in foster and kinship care from negative developmental outcomes by developing the foundations for learning, which may not be available in out-of-home placements (Meloy and Phillips 2012; Klein 2016). Although more research is needed, evidence is emerging that children who have experienced trauma can benefit from high-quality early childhood education and care services (Lipscomb et al. 2013; Kovan et al. 2014; Merritt and Klein 2015). Secure attachments formed in child care may also protect 
foster and kinship care children from the risk of problems arising in relationships with foster and kinship caregivers (Mathers et al. 2016).

Child care is also likely to have important, indirect effects on out-of-home care children that operate via caregivers. Child care may strengthen the resources and capabilities of caregivers if programs include significant engagement with parents and other caregivers. Child care is also an important employment support for families, enhancing family economic stability and, in turn, alleviating financial stress (Jordan et al. 2014; Mathers et al. 2016; Meloy and Phillips 2012; Pears et al. 2010). Child care can also provide respite from caregiving, alleviating caregiving stress, strengthening intentions to continue with the placement and, in turn, reducing the risk that a child will experience a placement disruption (Meloy and Phillips 2012).

\section{Use of Formal Child Care Among Australian Children in Foster and Kinship Care}

There is almost a complete absence of research on the use of formal child care among this population of children in Australia and very little research internationally (Klein 2016). In terms of child care attendance, findings from the Australian Pathways of Care Longitudinal Study (Australian Institute of Family Studies et al. 2015) and studies conducted in the US (Ringeisen et al. 2011; Lipscomb and Pears 2011) suggest that children in the child welfare system are just as likely, or more likely, to use centre-based child care as children in the general population.

Australian Government subsidies (including $50 \mathrm{~h}$ of weekly child care for fulltime grandparent caregivers receiving income support payments) combined with extra financial support towards out-of-pocket child care expenses provided by government child protection departments and foster and kinship care services make access easier (Australian Government, Department of Human Services, n.d.). However, barriers to child care access noted in research in England (Mathers et al. 2016), such as the uncertainty and mobility of out-of-home care placements and the shortage of child care placements for children with special needs and in areas outside major cities, are likely to apply in the Australian context.

There is insufficient research on the quality of child care foster and kinship care children experience, although in Australia more out-of-home care children live in remote and very remote locations where a lower proportion of services currently meet the National Quality Standard (Australian Children's Education and Care Quality Authority, ACECQA 2017). In terms of child care quantity, the Australian Pathways of Care Longitudinal Study showed that children in out-of-home care, aged 9-35 months, commonly spent relatively long hours in child care $30 \%$ were attending child care between 21 and $30 \mathrm{~h}$ per week, and $11 \%$ were attending child care for 31 or more hours per week), with hours spent in child care increasing with age (Australian Institute of Family Studies et al. 2015). This suggests out-of-home care children may have higher quantities of child care in terms of hours per week.

Although living with a single caregiving adult was associated with full-time early childhood education and care in the research by Lipscomb and Pears (2011), it is uncertain whether other placement and caregiver characteristics such as household 
income, parental employment, parent education, and family structure that predict the quality, quantity, and type of child care of children in the general population (NICHD Early Childcare Research Network 2005) apply in an out-of-home care context; or how a child's out-of-home care history (such as age for first out-of-home care admission, placement stability, number of out-of-home care admissions, and time in current placement) is associated with child care experience.

\section{Research Aims}

This study examines the proportion of very young children in foster and kinship care who use formal child care, weekly hours of child care, predictors of weekly hours of child care, and quality of care experienced. Understanding how child care is utilised, and who is most likely to use child care, will help inform actions that encourage child care decisions and arrangements for children in out-of-home care that can support improvement in children's learning and behaviour.

While there are few prior studies to inform specific hypotheses, it is expected that: (1) foster and kinship care children will be using child care to the same or a higher extent than their same-aged peers; (2) a slightly lower proportion of foster and kinship care children will be using child care that meets the Australian National Quality Standard (ACECQA 2017) compared to other children more generally; and (3) children looked after by caregivers who are more highly educated, employed, and not living with a partner will access more weekly child care hours.

\section{Method}

The current data are drawn from the Early Childhood in Foster and Kinship Care study (ECIFKC; http://www.fosterandkinship.com.au) which examined the learning and development of young foster and kinship care children across Australia. This study was undertaken by the University of Melbourne and the Berry Street Childhood Institute with funding from the Campbell Edwards Trust. The study invited foster and kinship caregivers of children who had yet to start school to take part in a web-based survey on their child's participation in early childhood education and care services, informal learning experiences and early development and well-being (Wise 2016). The study was promoted through a variety of communication channels by peak kinship and grandparent organisations, funded placement and support services and targeted early childhood education and care services. Information was collected from a total of 149 full-time foster and kinship caregivers between April 2015 and June 2016.

\section{Sample and Variables}

The sample used in these analyses consisted of 39 foster and kinship care children aged between 1 and 23 months of age ( $M=12.56$, SD 6.46). An extensive survey was completed online by foster and kinship caregivers, which generated descriptive data about the children, their caregivers, and out-of-home placements. Most primary 
variables for these analyses were coded as binary variables. Descriptive information on all variables considered in these analyses is presented in Table 3 in Appendix.

For geographic location, survey respondents recorded their postcodes, which were manually converted to one of five Australian Standard Geographical Classification Remoteness Areas using an online map locator (see http://www. doctorconnect.gov.au/internet/otd/publishing.nsf/Content/locator). For the current analysis, the Australian Standard Geographical Classification Remoteness Areas (RA) classification was dichotomised into $0=$ not a RA1-major city of Australia and $1=$ RA1 - major city of Australia.

To enable comparisons with Australian national samples, child care items were adapted from the Longitudinal Study of Australian Children and the Longitudinal Study of Indigenous Children. To capture use of child care and type of main child care, survey respondents recorded all formal child care types that the study child used from a list of ten response options; do not use child care, long day care centre, family day care, occasional care, gym, leisure or community centre, workplace crèche, Job Education Training (JET) crèche, mobile care unit, approved in-home care and other regulated child care. Using the same list of service types, respondents indicated which type of child care the study child used for the most hours each week (if applicable). The measure of weekly child care hours for children who use child care was based on responses to the item "How many hours per week does [study child] go to child care?". The measure of weekly child care hours for the whole sample (including children who do not use child care) was derived from responses to the item on weekly child care hours and the item on main type of child care, where "do not use child care" responses were assigned a value of zero weekly child care hours.

Whether the child's main child care service was meeting the Australian National Quality Standard (ACECQA 2017) or not was used as a proxy for program quality. Respondents recorded the name and address of the study child's main child care service, and the national registers were manually searched to identify the overall rating that the service received (see http://acecqa.gov.au/national-registers). The five rating levels on the National Quality Standard (NQS) are: excellent; exceeding the NQS; meeting the NQS; working towards the NQS; significant improvement required; and provisional-not yet assessed. This item was dichotomised into $0=$ meeting the NQS and $1=$ not meeting the NQS cases. If the service was not yet assessed, this was coded as missing.

Child behaviour problems were assessed by scores on the problems scale of the Brief Infant-Toddler Social Emotional Assessment (BITSEA; Briggs-Gowan and Carter 2002). Continuous problem scores were dichotomised into $0=$ below the cut-point for age and sex and $1=$ at or above the cut-point for age and sex.

\section{Data Analysis}

Statistical analyses were conducted with IBM SPSS Statistics 22.0. Frequency analyses were used to describe the proportion of ECIFKC children who used child care, as well as the mean weekly hours the children spend in child care; and the proportion of child care services that were meeting the National Quality Standard. For the total sample (including children who used zero weekly hours of child care), 
statistical differences between mean weekly hours of child care and all child, caregiver and placement variables were calculated using $t$ tests.

The contribution of child, caregiver, and placement variables to explain the variance in weekly child care hours across the total sample was investigated in a multiple regression analysis that included the categorical variables that indicated statistically significant differences on mean hours of weekly child care using the findings from the $t$ tests.

\section{Results}

\section{Use of Formal Child Care}

Figure 1 shows the proportion of ECIFKC children using formal child care in their first and second year and in their first 2 years compared to results for all Australian children from the Childhood Education and Care Survey, which collected data at 30 June 2014 (Australian Bureau of Statistics 2015). These data were collected at approximately the same time as the ECIFKC data collection and are comparable to the Australian Government child care administrative data calculated at 31 December 2014 (Steering Committee for the Review of Government Service Provision 2016). Most ECIFKC children (81.3\%) enrolled in formal child care used long day care services as their main child care arrangement. The three children who did not use long day care as their main formal child care arrangement used family day care $(n=2)$ and another form of regulated child care $(n=1)$. Only $8.3 \%$ of children using formal child care had commenced their main child care prior to living with their current foster or kinship caregiver.

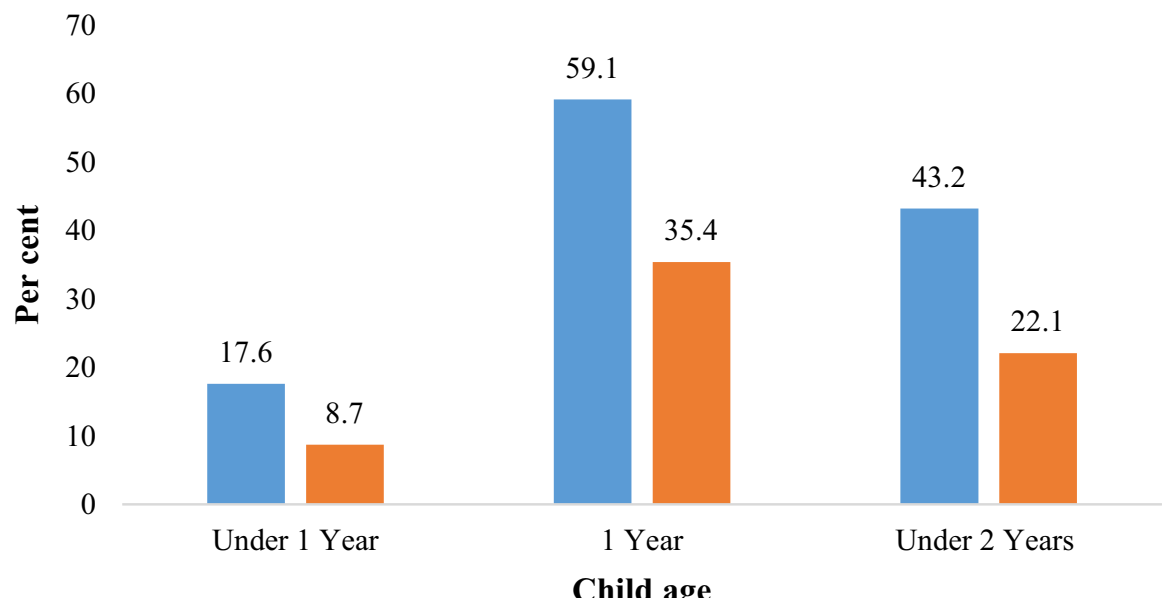

$\square$ ECIFKC $\square$ Australia

Fig. 1 Proportion of ECIFKC and Australian children using formal child care in the first 2 years 


\section{Weekly Hours of Formal Child Care}

Of the ECIFKC children who used child care, weekly hours ranged between 6 and $50 \mathrm{~h}$. The mean weekly hours of child care was 21.2 (SD 14.12). The Australian Bureau of Statistics does not publish weekly hours of child care disaggregated by age. However, of all Australian children (aged 0-5 years) who used long day care and family day care (i.e. excluding children who used before and/or after school care and occasional care), the mean weekly hours of child care was $20.6 \mathrm{~h}$ (author's calculations based on data from Australian Bureau of Statistics 2015). Australian Government child care administrative data on weekly child care hours were slightly higher at 27.7 weekly hours for long day care and 30.9 weekly hours for family day care (Steering Committee for the Review of Government Service Provision 2016).

\section{Quality of Main Child Care Arrangement}

Eight-three per cent of services used by ECIFKC children were meeting the National Quality Standard, in comparison to $68 \%$ of early childhood education and care services which were currently meeting the National Quality Standard across Australia in the fourth quarter 2015 (ACECQA 2016). These data were collected at approximately the same time as the ECIFKC data collection.

\section{Differences in Hours of Child Care by Child, Caregiver, and Placement Variables}

Differences in weekly child care hours among ECIFKC children were compared across 18 dichotomous variables (see Table 1). There was a significant difference in weekly child care hours by age for children aged less than 1 year compared to children of 1 year of age, $t(37)=-3.25, p=.002$; for children who lived with siblings versus children who did not live with siblings, $t(37)=-3.90, p=.000$; and for caregivers not partnered compared to caregivers partnered; $t(37)=2.81, p=.008$.

\section{Explaining Variations in Weekly Hours of Child Care}

To investigate the contribution of sibling co-placement, child age and caregiver relationship status to the explanation of variance of weekly child care hours, the selected variables were included in a multiple linear regression model (Table 2). These variables explained a significant amount of variation in weekly hours of child care $F(3,35)=9.044, p<.000$, with an $R^{2}=.437, R^{2}$ adjusted $=.388$. Children living in placements with a single caregiver spent 10.3 more weekly hours in child care, children who were in their second year of life spent 7.6 more weekly hours in child care, and children placed with siblings spent 11.4 more weekly hours in child care. Caregiver relationship status and sibling co-placement significantly predicted average hours of child care per week $(p<.05)$ and child age approached significance $(p=.057)$. 
Table 1 Differences in mean weekly hours of child care by child, caregiver, and placement variables

\begin{tabular}{|c|c|c|c|c|c|c|}
\hline & $n$ & $M$ & SD & $t$ & $d f$ & $\operatorname{sig}$ \\
\hline \multicolumn{7}{|l|}{ Child characteristics } \\
\hline Child is male & 21 & 7.88 & 12.24 & & & \\
\hline Child is female & 18 & 9.61 & 15.70 & -.387 & 31 & .701 \\
\hline Child is $<1$-year-old & 17 & 1.38 & 3.16 & & & \\
\hline Child is 1-year-old & 22 & 14.32 & 16.11 & -3.25 & 37 & $.002 * *$ \\
\hline Child does not have a disability or health condition & 30 & 8.00 & 13.19 & & & \\
\hline Child has a disability or health condition & 9 & 10.94 & 16.23 & -.58 & 37 & .581 \\
\hline Child is non-Aboriginal & 29 & 8.07 & 14.15 & & & \\
\hline Child is Aboriginal & 10 & 10.45 & 13.20 & -.47 & 37 & 644 \\
\hline Child does not live in a major city & 16 & 7.50 & 11.31 & & & \\
\hline Child lives in a major city & 23 & 9.50 & 15.36 & -.44 & 37 & .662 \\
\hline $\begin{array}{l}\text { Child's BITSEA problem score below cut-point for age } \\
\text { and sex }\end{array}$ & 18 & 12.67 & 14.90 & & & \\
\hline $\begin{array}{l}\text { Child's BITSEA problem score at or above cut-point for } \\
\text { age and sex }\end{array}$ & 3 & 17.33 & 24.21 & -.46 & 19 & 648 \\
\hline \multicolumn{7}{|l|}{ Placement characteristics } \\
\hline Child does not live with sibling/s & 31 & 4.95 & 8.78 & & & \\
\hline Child lives with sibling/s & 8 & 23.13 & 20.00 & -3.90 & 37 & $.000 * * *$ \\
\hline Child has lived with caregiver $<3$ months & 9 & 2.39 & 5.01 & & & \\
\hline Child has lived with primary caregiver $3+$ months & 21 & 9.19 & 12.90 & -1.52 & 28 & .140 \\
\hline Child has not lived with caregiver since birth & 25 & 9.90 & 14.16 & & & \\
\hline Child has lived with primary caregiver since birth & 14 & 6.50 & 13.31 & .74 & 37 & .467 \\
\hline Child not expected to live with caregiver permanently & 25 & 7.94 & 14.28 & & & \\
\hline $\begin{array}{l}\text { Child expected to live with primary caregiver } \\
\text { permanently }\end{array}$ & 13 & 10.77 & 13.46 & -.59 & 36 & .559 \\
\hline \multicolumn{7}{|l|}{ Caregiver characteristics } \\
\hline Primary caregiver a friend/relative & 7 & 16.50 & 21.39 & & & \\
\hline Primary caregiver a foster caregiver & 32 & 7.25 & 12.04 & -1.52 & 33 & .139 \\
\hline Primary caregiver is male & 3 & 10.67 & 9.24 & & & \\
\hline Primary caregiver is female & 35 & 7.76 & 13.62 & .36 & 36 & .721 \\
\hline Primary caregiver is not Indigenous & 36 & 8.76 & 14.23 & & & \\
\hline Primary caregiver is Indigenous & 3 & 7.67 & 8.02 & .05 & 36 & .958 \\
\hline Primary caregiver is not partnered & 7 & 20.86 & 22.21 & & & \\
\hline Primary caregiver is partnered & 32 & 6.02 & 9.82 & 2.81 & 37 & $.008 * *$ \\
\hline Primary caregiver not employed & 20 & 5.25 & 13.39 & & & \\
\hline Primary caregiver employed & 14 & 12.93 & 13.80 & 1.63 & 32 & .114 \\
\hline Primary caregiver has not completed Year 12 education & 10 & 6.60 & 16.06 & & & \\
\hline Primary caregiver has completed Year 12 education & 24 & 9.17 & 13.19 & -.49 & 32 & 631 \\
\hline Primary caregiver has fair or poor health & 1 & .00 & & & & \\
\hline Primary caregiver has good health & 34 & 8.63 & 13.81 & -6.16 & 33 & .542 \\
\hline
\end{tabular}


Table 1 continued

\begin{tabular}{|c|c|c|c|c|c|c|}
\hline & $n$ & $M$ & SD & $t$ & $d f$ & sig \\
\hline $\begin{array}{l}\text { Household financial status not reasonably comfortable or } \\
\text { better }\end{array}$ & 5 & 14.80 & 22.25 & & & \\
\hline $\begin{array}{l}\text { Household financial status reasonably comfortable or } \\
\text { better }\end{array}$ & 30 & 7.32 & 11.96 & 1.14 & 33 & .264 \\
\hline
\end{tabular}

$* * p<.01 ; * * * p<.001$

Table 2 Coefficients from multiple linear regression analysis predicting weekly child care hours using significant child, caregiver and placement characteristics

${ }^{+} p<.10 ; * p<.05$

\begin{tabular}{ll}
\hline & Hours of weekly child care \\
\hline Predictors & $\beta$ \\
Sibling co-placement & $.340^{*}$ \\
Caregiver relationship status & $-.291^{*}$ \\
Child age & $.297^{+}$ \\
Total $R^{2}$ & .437 \\
$N$ & 39 \\
\hline
\end{tabular}

\section{Discussion}

While child care was expected to be part of the daily lives of ECIFKC children to, at least the same extent as children generally, approximately double the proportion of ECIFKC children used child care compared to same age Australian children generally (43.2\% of ECIFKC children used child care compared to $22.0 \%$ of the population). There was also a higher proportion of ECIFKC children who used child care than children in the Longitudinal Study of Indigenous Children $(27.0 \%$ of children at 2 years of age; Holzinger and Biddle 2015). As weekly hours of child care increases with age, it is reasonable to assume that ECIFKC children also used more weekly hours of child care than other Australian children in their first 2 years. ECIFKC children spent on average $20.2 \mathrm{~h}$ per week in formal child care settings (predominantly long day care centres) compared to an average of $20.6 \mathrm{~h}$ for the entire population of children using long day care and family day care (approximately 0-5 years). Over one-third of ECIFKC children used more than 20 weekly hours of child care.

While it was expected that a lower proportion of ECIFKC children would be using child care that met the National Quality Standard (since more out-of-home care children live outside major cities where there is a lower proportion of early childhood education and care services meeting the National Quality Standard), the quality of child care used by ECIFKC children was broadly the same as for Australian children generally.

The presence of a sibling in the home and being looked after by a single caregiver were significant predictors of weekly child care hours. There were no associations between other caregiver characteristics (e.g. caregiver education, employment) and weekly child care hours as expected. 
Taken together, this analysis shows that a high proportion of ECIFKC children were exposed to the effects of ordinarily good (or better) child care for a high number of weekly hours, often for more than 20 weekly hours (in over one-third of cases). The greater proportion of children using child care who were looked after by a single caregiver and with a sibling in the home suggests that the purpose of child care for many ECIFKC children may have been to assist caregivers with respite, although this study has several limitations including a small sample size so that findings cannot be generalised to the broader population of foster and kinship care children. However, the finding that a high proportion of very young foster and kinship care children use child care is in line with prior studies. It also suggests attention needs to be paid to the reasons foster and kinship care children are being referred to child care services as well as the quality and quantity that foster and kinship care children receive.

It is difficult to say whether the quantity and quality of child care that ECIFKC children used is desirable or not (Klein 2016). While the literature cautions against long weekly hours of child care, particularly in the first year, $20 \mathrm{~h}$ of weekly child care in a regulated service that is meeting the National Quality Standard may not pose a problem for child development if stress levels are not affected while at child care and if relationships with foster and kinship caregivers are not adversely affected. Children may even benefit if they can take advantage of learning opportunities, and form close, trusted relationships with early childhood education and care providers. Whether using child care for respite is appropriate, or in the child's best interest, is uncertain, although the suitability of the out-of-home care placement, or whether child care was strengthening an appropriate long-term care option, would seem to be important.

Although a child's placement circumstances may prescribe the use of child care for respite, there is little evidence that child care is beneficial for foster and kinship care children with attachment and behaviour problems, and it is unclear whether services that meet the National Quality Standard can respond appropriately to the special needs of foster and kinship care children (Mathers et al. 2016). Child care that targets children who experience significant family stress and social disadvantage to support self-regulation and develop their academic potential can aim to deliver sensitive adult support through trauma and attachment informed practice (Jordan et al. 2014). The structural features of such specialised programs (e.g. favourable adult-child ratios and staff qualifications) would be typically above regulatory requirements. Experts and key stakeholders in England have also recognised that a mainstream formal early learning setting may not be suitable for out-of-home care children (Mathers et al. 2016).

\section{Implications for Policy and Practice}

A large proportion of very young foster and kinship care children are likely to be using long hours of child care in the first 2 years and that these long hours offer respite for caregivers could be a driving factor. While there is little empirical data to indicate whether child care should be promoted for foster and kinship care children and what type of arrangements should be encouraged (Klein 2016), very long hours 
in group-care arrangements should be avoided (unless there are significant problems in the placement) and high-quality services that address the special needs of foster and kinship care children should be supported. While there are no Australian data, UK research indicates improvements can be made in this area (Mathers et al. 2016).

In-home child care by a qualified early childhood education and care professional is another potentially useful way of avoiding child care services that do not meet the needs of very young foster and kinship care children as well as supporting caregivers who require respite and parenting education and support. The Australian Government already makes in-home child care available to families in special circumstances when an approved educator is monitored and supported by an approved agency (e.g. child care centre or family day care scheme). While foster and kinship caregivers may meet the current criteria for access to in-home child care, such as living in a rural or remote area or caring for three or more children who have not yet started school, the Australian Government could extend access to inhome child care to children in full-time foster and kinship care or create new inhome care places for this population. Partnership agreements between foster care and kinship care services and early childhood education and care services, if appropriately communicated to foster and kinship caregivers, would be a another approach to support early childhood education and care professionals to work in a specialised way with out-of-home care children and their caregivers.

The research findings also raise the issue of child care staff training and understanding of the special needs of foster and kinship care children. Foster and kinship care children represent only a small proportion of the general population, and meeting their varying needs is complex requiring internal support structures and supervision, staffing levels and staff knowledge and expertise (Mathers et al. 2016). Any new support services should be targeted at services that can demonstrate effectiveness in working with children requiring additional attention and support.

New supports could include funding for roles such as the South Australian Family Services Coordinators (South Australia Department for Education and Child Development, n.d.). These support staff work alongside child care centre staff and allied health workers to support families with vulnerabilities, provide advice on the effects of trauma, abuse and neglect, liaise with child protection workers and deliver programs such as the Circle of Security that focus on relationships, social and emotional well-being and recovery from trauma. Alternatively, funding could be provided to service providers to pay for extra training of existing early childhood education and care professionals and staff replacements to allow time off to attend training, meetings and appointments and for specialist interventions such as mental health and allied health support. Funding is also needed for supervision and support structures, either provided in-house or through implementing models of integrated practice and peer support. Pre-purchasing places in funded services could ensure that places are available for foster and kinship care children at times when child care support is needed.

Finally, capturing a child's out-of-home care status in the Australian Government Department of Education and Training child care administrative data collection and in the Australian Bureau of Statistics Childhood Education and Care Survey would support ongoing national monitoring of out-of-home care children's use of child 
care and the quality of service provision. The impacts of child care use on early academic performance could also be investigated by linking data from administrative records to data from the Australian Early Development Census (Australian Government, Department of Education and Training 2016) and the National Assessment Program-Literacy and Numeracy (Australian Curriculum, Assessment and Reporting Authority 2017).

\section{Conclusion}

Very young children in foster and kinship care may have attachment and behaviour problems and need consistent and stable caregiving environments where they can begin to trust adults and form close relationships. They also need educational opportunities to support their social-emotional development and early learning. Depending on a range of factors, child care arrangements may be consistent with, or contradictory to these goals. Long hours in child care that do not meet the special needs of foster and kinship care children is likely to increase developmental vulnerability.

A high proportion of children in foster and kinship care in the current analysis were enrolled in long hours of weekly child care. While the majority were accessing child care that met the National Quality Standard, the long hours some children spent in child care is concerning, as it is unclear whether ordinarily good child care can meet the special needs of foster and kinship care children. Children placed with single caregivers and children placed with siblings spend many more average weekly hours in child care. This suggested that child care may be used for respite for the adult caregiver. In such circumstances, child care may contribute positively to child development through indirect pathways, by supporting caregivers who might otherwise feel overwhelmed with the demands of caregiving and discontinue the placement. Because of the small sample size in this study, it is not possible to generalise findings to other foster and kinship care children. However, in policy and practice, attention needs to be paid to the reasons foster and kinship care children are being referred to child care services as well as the quality and quantity of child care they experience.

The available evidence suggests avoiding long hours in group-care arrangements for young children and promoting access to specialised child care for children in foster and kinship care. Initiatives that support professionals and caregivers to make informed child care decisions, offering new in-home care support services and equipping certain child care services to address the special needs of foster and kinship care children by keeping stress levels low across the day may be productive ways forward. Capturing a child's out-of-home care status with the national child care administrative records and linking this dataset with the Australian Early Development Census and the National Assessment Program for Literacy and Numeracy datasets would also support the monitoring of child care use and its effects on learning and development among out-of-home care children. 
Acknowledgements The Early Childhood in Foster and Kinship Care study was supported by a grant from the Campbell Edwards Trust.

Open Access This article is distributed under the terms of the Creative Commons Attribution 4.0 International License (http://creativecommons.org/licenses/by/4.0/), which permits unrestricted use, distribution, and reproduction in any medium, provided you give appropriate credit to the original author(s) and the source, provide a link to the Creative Commons license, and indicate if changes were made.

\section{Appendix}

\section{See Table 3.}

Table 3 Summary statistics of variables used in the analysis

Number of
observations $\quad$ Mean $S D$

\section{Child characteristics}

Study child is 1 year old

( 0 = study child is $<12$ months, $1=$ study child is $12+$ months)

Study child is female

( $0=$ study child is male, $1=$ study child is female)

Study child has a disability or medical condition

$(0=$ study child does not have a disability or health condition,

$1=$ study child does have a disability or health condition)

Study child is Indigenous

( $0=$ study child is not Indigenous, $1=$ study child is Indigenous)

ASGC-RA = RA1 (major city)

( 0 = ASGC-RA is RA2, RA3, RA4 or RA5, 1 = ASGC-RA is 1)

BITSEA problem score at or above cut for age and sex*

$(0=$ BITSEA problem score below cut-point for age and sex,

$1=$ BITSEA problem score at or above cut-point for age and sex)

\section{Placement characteristics}

Study child lives with sibling/s

$(0=$ study child does not live with sibling/s, $1=$ study child lives with siblings)

Study child has lived with primary caregiver $3+$ months

$(0=$ study child lived with caregiver $<3$ months, $1=$ study child lived with caregiver $3+$ months)

Study child lived with primary caregiver since birth

$(0=$ study child not lived with primary caregiver since birth,

$1=$ study child lived with primary caregiver since birth) 
Table 3 continued

\begin{tabular}{|c|c|c|c|}
\hline & $\begin{array}{l}\text { Number of } \\
\text { observations }\end{array}$ & Mean & $S D$ \\
\hline Months study child has lived with primary caregiver & 30 & 9.367 & 6.333 \\
\hline $\begin{array}{l}\text { Study child is expected to live with primary caregiver permanently } \\
(0=\text { study child not expected to live with caregiver permanently, } \\
1=\text { study child expected to live with caregiver permanently) }\end{array}$ & 38 & .342 & .481 \\
\hline Caregiver characteristics & & & \\
\hline Age of primary caregiver & 38 & 44.474 & 9.80 \\
\hline $\begin{array}{l}\text { Primary caregiver is a foster caregiver } \\
(0=\text { primary caregiver is a kinship caregiver, } 1=\text { primary } \\
\text { caregiver is foster caregiver })\end{array}$ & 39 & .821 & .389 \\
\hline $\begin{array}{l}\text { Primary caregiver is female } \\
(0=\text { primary caregiver is male, } 1=\text { primary caregiver is female })\end{array}$ & 38 & .921 & .273 \\
\hline $\begin{array}{l}\text { Primary caregiver is Indigenous } \\
(0=\text { primary caregiver is not Indigenous, } 1=\text { primary caregiver is } \\
\text { Indigenous })\end{array}$ & 38 & .079 & .273 \\
\hline $\begin{array}{l}\text { Primary caregiver is partnered } \\
(0=\text { primary caregiver is not partnered, } 1=\text { primary caregiver is } \\
\text { partnered })\end{array}$ & 39 & .821 & .389 \\
\hline $\begin{array}{l}\text { Primary caregiver is employed } \\
(0-=\text { primary caregiver not employed, } 1=\text { primary caregiver } \\
\text { employed })\end{array}$ & 34 & .529 & .507 \\
\hline $\begin{array}{l}\text { Primary caregiver has completed Year } 12 \text { education } \\
(0=\text { primary caregiver has not completed Year } 12,1=\text { primary } \\
\text { caregiver has completed Year } 12)\end{array}$ & 34 & .706 & .463 \\
\hline $\begin{array}{l}\text { Primary caregiver has good health } \\
(0=\text { caregiver has fair or poor health, } 1=\text { caregiver has good } \\
\text { health or better })\end{array}$ & 35 & .971 & .169 \\
\hline $\begin{array}{l}\text { Primary caregiver rates household financial status as reasonably } \\
\text { comfortable or better } \\
(0=\text { primary caregiver does not rate household financial status as } \\
\text { reasonably comfortable or better, } 1=\text { does rate household } \\
\text { financial status as reasonably comfortable or better) }\end{array}$ & 35 & .857 & .355 \\
\hline Child care characteristics & & & \\
\hline $\begin{array}{l}\text { Study child attends playgroup } \\
(0=\text { study child does not attend playgroup, } 1=\text { study child attends } \\
\text { playgroup })\end{array}$ & 38 & .526 & .506 \\
\hline $\begin{array}{l}\text { Study child attends formal child care } \\
(0=\text { study child does not attend child care, } 1=\text { study child attends } \\
\text { child care })\end{array}$ & 37 & .432 & .502 \\
\hline $\begin{array}{l}\text { Study child commenced main child care prior to living with foster/ } \\
\text { kinship caregiver } \\
(0=\text { study child commenced main child care after living with } \\
\text { primary caregiver, } 1=\text { study child commenced main child care } \\
\text { prior to living with foster/kinship caregiver })\end{array}$ & 12 & .083 & .289 \\
\hline $\begin{array}{l}\text { Weekly hours of formal child care (children who usually attend } \\
\text { formal child care) }\end{array}$ & 16 & 21.16 & 14.12 \\
\hline
\end{tabular}


Table 3 continued

Number of

observations

Study child uses long day care as MAIN formal child care arrangement (children who usually attend formal child care)

$(0=$ main weekly child care arrangement is not long day care,

$1=$ main weekly child care arrangement is long day care)

Study child attends more than one weekly formal child care arrangement (children who usually attend formal child care)

$(0=$ study child attends one weekly child care arrangement only, $1=$ study child attends more than one weekly child care arrangement)

Study child's main child care not meeting the National Quality Standard $(0=$ study child's main child care meeting the National Quality Standard, 1 = study child's main child care not meeting the National Quality Standard)
16

.403

*Ages 12-23 months

\section{References}

Anda, R. F., Felitti, V. J., \& Bremner, J. D. (2006). The enduring effects of abuse and related adverse experiences in childhood: A convergence of evidence from neurobiology and epidemiology. European Archives of Psychiatry and Clinical Neuroscience, 256, 174-186.

Australian Bureau of Statistics. (2015). 4402.0_Childhood Education and Care, Australia, June 2014. Retrieved from http://www.abs.gov.au/AUSSTATS/abs@.nsf/DetailsPage/4402.0June\%202014 ?OpenDocument.

Australian Children's Education and Care Quality Authority. (2016). NQF snapshot Q4 2015. A quarterly report from the Australian Children's Education and Care Quality Authority. Retrieved from http:// files.acecqa.gov.au/files/Reports/2015/NQF\%20Snapshot\%20Q4\%202015.pdf.

Australian Children's Education and Care Quality Authority. (2017). NQF snapshot Q1 2017. A quarterly report from the Australian Children's Education and Care Quality Authority. Retrieved from http:// files.acecqa.gov.au/files/Reports/2017/NQF_Snapshot_Q1_2017.PDF.

Australian Curriculum, Assessment and Reporting Authority. (2017). NAPLAN achievement in reading, writing, language conventions and numeracy: National report for 2017. Sydney: ACARA. Retrieved from http://www.nap.edu.au/results-and-reports/national-reports.

Australian Government, Department of Education and Training. (2016). Australian Early Development Census (AEDC) National Report 2015: A snapshot of early childhood development in Australia. Australian Government, Department of Education and Training. Retrieved from https://www.aedc. gov.au/resources/reports.

Australian Government, Department of Human Services. (n.d). Support for non parent carers. Retrieved from https://www.humanservices.gov.au/individuals/subjects/support-non-parent-carers.

Australian Institute of Family Studies, Chapin Hall Center for Children University of Chicago, \& New South Wales Department of Family and Community Services. (2015). Pathways of care longitudinal study: Outcomes of children and young people in out-of-home care in NSW. Wave 1 baseline statistical report. Sydney: N.S.W. Department of Family and Community Services. Retrieved from http://www.community.nsw.gov.au/_data/assets/file/0004/335866/pathways_of_care_research_ report.pdf.

Australian Institute of Health and Welfare. (2015). Literature review of the impact of early childhood education and care on learning and development: Working paper. Cat. No. CWS 53. Canberra: AIHW. 
Australian Institute of Health and Welfare. (2017). Child protection Australia 2015-16. Child welfare series no. 66. Cat. No. CWS 60. Canberra: AIHW.

Baker, M., Gruber, J., \& Milligan, K. (2008). Universal child care, maternal labor supply, and family well-being. Journal of Political Economy, 116(4), 709-745.

Barnes, J., \& Melhuish, E. (2017). Amount and timing of group-based childcare from birth and cognitive development at 51 months: A UK study. International Journal of Behavioural Development, 41(3), 360-370.

Belsky, J., Vandell, D. L., Burchinal, M., Clarke-Stewart, K. A., McCartney, K., \& Owen, M. T. (2007). NICHD early child care research network. Child Development, 78(2), 681-701.

Berry, D., Blair, C., Willoughby, M., Garrett-Peters, P., Vernon-Feagans, L., Mills-Koonce, W. R., et al. (2016). Household chaos and children's cognitive and socio-emotional development in early childhood: Does childcare play a buffering role? Early Childhood Research Quarterly, 34, 115-127.

Briggs-Gowan, M. J., \& Carter, A. S. (2002). Brief infant-toddler social and emotional assessment (BITSEA) manual, version 2.0. New Haven, CT: Yale University.

Bruce, J., Fisher, P. A., Pears, K. C., \& Levine, S. (2009). Morning cortisol levels in preschool-aged foster children: Differential effects of maltreatment type. Developmental Psychobiology, 51(1), 14-23.

Casanueva, C., Ringeisen, H., Wilson, E., Smith, K., \& Dolan, M. (2011). NSCAW II baseline report: Child well-being (OPRE Report \#2011-27b). Washington, DC: Office of Planning, Research and Evaluation, Administration for Children and Families, U.S. Department of Health and Human Services. Retrieved from https://www.acf.hhs.gov/sites/default/files/opre/nscaw2_child.pdf.

Committee on Psychosocial Aspects of Child and Family Health, Committee on Early Childhood, Adoption, and Dependent Care and Section on Developmental and Behavioral Pediatrics, Shonkoff, J. P., Siegel, B. S., Dobbins, M. I., et al. (2011). Early childhood adversity, toxic stress, and the role of the pediatrician: Translating developmental science into lifelong health. Pediatrics, 129(1), e224e231. Retrieved from http://pediatrics.aappublications.org/content/pediatrics/early/2011/12/21/peds. 2011-2662.full.pdf.

Hanson, K., \& Hawkes, D. (2009). Early childcare and child development. Journal of Social Policy, 38(2), 211-239.

Holzinger, L. A., \& Biddle, N. (2015). The relationship between Early Childhood Education and Care (ECEC) and the Outcomes of Indigenous Children: Evidence from the Longitudinal Study of Indigenous Children (LSIC). CAEPR working paper no. 103/2015. Canberra: Centre for Aboriginal Economic Policy Research ANU College of Arts and Social Sciences. Retrieved from http://caepr. anu.edu.au/sites/default/files/Publications/WP/Working\%20Paper\%20103-15.pdf.

Jaffe, S. R., Van Hulle, C., \& Rodgers, J. L. (2011). Effects of nonmaternal care in the first 3 years on children's academic skills and behavioral functioning in childhood and early adolescence: A sibling comparison study. Child Development, 82, 1076-1091.

Jordan, B., Tseng, Y. P., Coombs, N., Kennedy, A., \& Borland, J. (2014). Improving lifetime trajectories for vulnerable young children and families living with significant stress and social disadvantage: The early years education program randomized control trial. BioMed Central Public Health, 14, 965.

Kalb, G., Tabasso, D., \& Zakirova, R. (2014). Children's participation in early childhood education and care, and their developmental outcomes by year 5: A comparison between disadvantaged and advantaged children. Report for the Department of Education, Employment and Workplace Relations, Melbourne Institute of Applied Economic and Social Research, University of Melbourne. Retrieved from http://melbourneinstitute.unimelb.edu.au/assets/documents/sprs-reports/4-13_Final_ Report.pdf.

Klein, S. (2016). Promising evidence regarding the benefits of early care and education for children in the child welfare system. OPRE report \# 2016-68. Washington, DC: Office of Planning, Research and Evaluation, Administration for Children and Families, U.S. Department of Health and Human Services

Kovan, N., Mishra, S., Susman-Stillman, A., Piescher, K. N., \& LaLiberte, T. (2014). Differences in the early care and education needs of young children involved in child protection. Children and Youth Services Review, 46, 139-145.

Lang, K., Bovenschen, I., Gabler, S., Zimmerman, J., Nowacki, K., Kliewer, J., et al. (2016). Foster children's attachment security in the first year after placement: A longitudinal study of predictors. Early Childhood Research Quarterly, 36, 269-280.

Lipscomb, S. T., \& Pears, K. C. (2011). Patterns and predictors of early care and education for children in foster care. Children and Youth Services Review, 33, 2303-2311. 
Lipscomb, S. T., Pratt, M. E., Schmitt, S. A., Pears, K. C., \& Kim, H. K. (2013). School readiness in children living in non-parental care: Impacts of Head Start. Journal of Applied Developmental Psychology, 34(1), 28-37.

Loeb, S., Bridges, M., Bassok, D., Fuller, B., \& Rumberger, R. W. (2007). How much is too much? The influence of preschool centers on children's social and cognitive development. Economics of Education Review, 26, 52-66.

Love, J. M., Kisker, E. E., Ross, C., Raikes, H., Constantine, J., Boller, K., et al. (2005). The effectiveness of early head start for 3-year-old children and their parents: Lessons for policy and programs. Developmental Psychology, 41(6), 885-901.

Mathers, S., Hardy, G., Clancy, C., Dixon, J., \& Harding, C. (2016). Starting out right: Early education and looked after children. London: University of Oxford/Family and Childcare Trust. Retrieved from http://www.education.ox.ac.uk/wordpress/wp-content/uploads/2010/07/Starting-out-right_ LAC-and-early-education_Dec-2016-1.pdf.

Melhuish, E. C. (2004). A literature review of the impact of early years provision upon young children. London: National Audit Office. Retrieved from http://media.nao.org.uk/uploads/2004/02/268_ literaturereview.pdf.

Melhuish, E. C. (2010). Why children, parents and home learning is important. In K. Sylva, E. Melhuish, P. Sammons, I. Siraj-Blatchford, \& B. Taggart (Eds.), Early childhood matters: evidence from the effective pre-school and primary education project (Vol. 2010, pp. 44-69). London: Routledge.

Melhuish, E., Ereky-Stevens, K., Petrogiannis, K., Ariescu, A., Penderi, E., Rentzou, K., Tawell, A., Slot, P., Broekhuizen, M., \& Leseman, P. (2015). A review of research on the effects of Early Childhood Education and Care (ECEC) upon child development. Care project; Curriculum quality Analysis and Impact Review of European Early Childhood Education and Care (ECEC). Retrieved from http://ecec-care.org/resources/publications/.

Meloy, M. E., \& Phillips, D. A. (2012). Foster children and placement stability: The role of child care assistance. Journal of Applied Developmental Psychology, 33, 252-259.

Merritt, D. H., \& Klein, S. (2015). Do early care and education services improve language development for maltreated children? Evidence from a national child welfare sample. Child Abuse and Neglect, 39, 185-196.

NICHD Early Childcare Research Network. (2004). Type of child care and children's development at 54 months. Early Childhood Research Quarterly, 19, 203-230.

NICHD Early Childcare Research Network. (2005). Child care and child development: Results from the NICHD study of early child care and youth development. New York: The Guilford Press.

Pears, K. C., Bruce, J., Fisher, P. A., \& Kim, H. K. (2010). Indiscriminate friendliness in maltreated foster children. Child Maltreatment, 15, 64-75.

Pechtel, P., \& Pizzagalli, D. A. (2010). Effects of early life stress on cognitive and affective function: An integrated review of human literature. Psychopharmacoloy, 214(1), 55-70.

Ringeisen, H., Casanueva, C., Smith, K., \& Dolan, M. (2011). NSCAW II baseline report: Children's services (OPRE report \# 2011-27f). Washington, DC: Office of Panning, Research and Evaluation, Administration for Children and Families, U.S. Department of Health and Human Services.

South Australia Department for Education and Child Development. (n.d.). Family services program. Retrieved from https://www.decd.sa.gov.au/parenting-and-child-care/childcare/services-andprograms/childrens-centres/childrens-centre-programs/familyservices-program.

Steering Committee for the Review of Government Service Provision. (2016). Report on Government Services 2016, vol. B, Child care, education and training. Canberra: Productivity Commission. Retrieved from http://www.pc.gov.au/research/ongoing/report-on-government-services/2016/ childcare-education-and-training/rogs-2016-volumeb-child-care-education-and-training.pdf

Sylva, K., Melhuish, E., Sammons, P., Siraj-Blatchford, I., \& Taggart, B. (2004). The effective provision of pre-school education (EPPE) project: Findings from pre-school to end of key stage 1. Nottingham: Department for Education and Skills. Retrieved from http://ro.uow.edu.au/cgi/ viewcontent.cgi ?article $=3155 \&$ context $=$ sspapers.

Sylva, K., Melhuish, E., Sammons, P., Siraj-Blatchford, I., \& Taggart, B. (Eds.). (2010). Early childhood matters: Evidence from the effective pre-school and primary education project. London: Routledge.

Wise, S. (2016). High quality early childhood education and care can help address education inequality: Background to the Early Childhood in Foster and Kinship Care study. Developing Practice, 45, 45-53.

Yamauchi, C., \& Leigh, A. (2011). Which children benefit from non-parental care? Economics of Education Review, 30(6), 1468-1490. 